\title{
Nonagricultural Demand Causes Agricultural Land Values to Increase ${ }^{1}$
}

John E. Reynolds ${ }^{2}$

The 2004 Florida Land Value Survey results indicate that the value of all types of agricultural land increased substantially in all regions of the state from 2003 to 2004. The market for agricultural land was very active this past year and the rate of increase in land values was particularly high in the South region. The percentage change in most categories was in the double-digits. Survey respondents indicated that increases in agricultural land values were primarily due to strong nonagricultural demand for land.

Agricultural land values vary by the type of land use and geographic area. The survey results indicate that the average value for agricultural land ranges from approximately $\$ 1,500$ per acre for unimproved pasture and farm woods in the Northwest region to over $\$ 6,500$ for orange groves in the South region.

The Florida Land Value Survey, conducted by the Food and Resource Economics Department at the University of Florida, provides estimates of the value of different types of agricultural land for geographic regions of the state. The survey questionnaire was designed to obtain estimates of the market value for different types of land as of May of 2004. Survey respondents included rural appraisers, farm lenders, real estate brokers, farm managers, land investors, county extension agents, personnel from the Farm Services Agency and the Natural Resource Conservation Service, county property appraisers, and other persons who develop and maintain information about rural land values in their areas. Respondents provided 195 usable county reports for the 2004 survey.

Florida was divided, based on agricultural production, into five major regions: Northwest, Northeast, Central, South, and Southeast (Figure 1). The Southeast region was delineated as a result of the impact of urbanization in southeast Florida. Even though the state was divided into more homogeneous regions, wide variation in agricultural land values still exists within each region.

\section{Changes by Type of Land Use}

The value of agricultural land increased in all regions. The value of cropland increased 9 to 58 percent, and the value of improved and unimproved pastureland increased 9 to 76 percent. The value of farm woods increased 16 to 18 percent. Although citrus groves did not increase as much as cropland

1. This is EDIS document FE545, a publication of the Department of Food and Resource Economics, Florida Cooperative Extension Service, Institute of Food and Agricultural Sciences, University of Florida, Gainesville, FL. Published April 2005. Please visit the EDIS website at http://edis.ifas.ufl.edu.

2. John E. Reynolds, Professor Emeritus, Department of Food and Resource Economics, Florida Cooperative Extension Service, Institute of Food and Agricultural Sciences, University of Florida, Gainesville, FL 32611, and Appraiser/Consultant,Natural Resource Planning Services, 5700 SW 34 Street, Suite 324, Gainesville, FL 32608. 


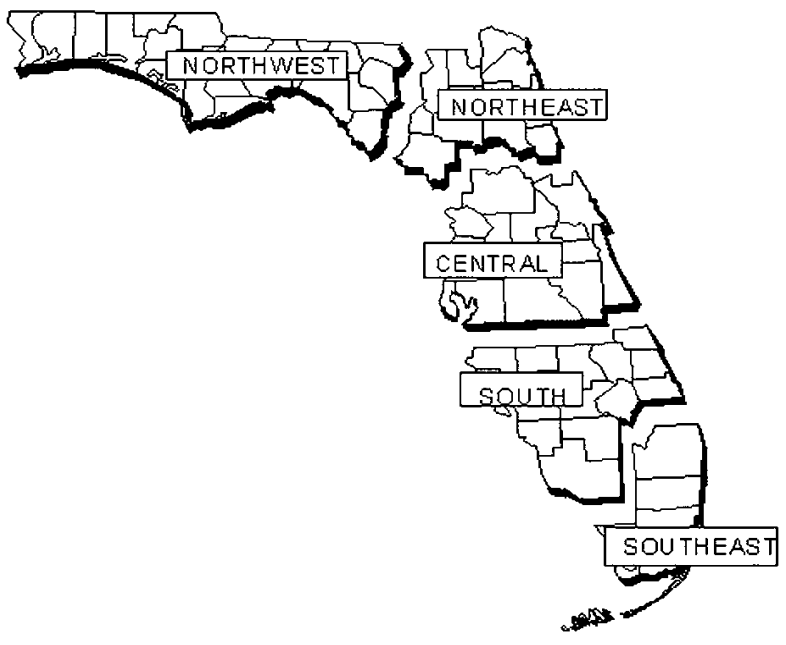

Figure 1. Geographic regions used for the Florida land value survey.

and pasture, the value of orange groves and 5- to 7-year-old citrus groves increased 9 to 12 percent, and the value of grapefruit groves increased 15 to 34 percent (Table 1).

Citrus. The value of orange and grapefruit groves increased in both the Central and South regions. The value of orange groves increased 10 percent in the South region and 12 percent in the Central region. The value of grapefruit groves increased 34 percent in the South region and 15 percent in the Central region. The value of land with 5- to 7-year-old citrus plantings increased about 9 percent in the South and Central regions.

Cropland. The value of cropland increased in all regions. The value of irrigated cropland increased 58 percent in the South region, 24 percent in the Central region, and about 10 percent in the Northeast and Northwest regions. The value of nonirrigated cropland increased 25 percent in the Central region, 19 percent in the Northwest region, and 12 percent in the Northeast region. There were insufficient data on the value of nonirrigated cropland in the South region to provide a reliable estimate.

Pastureland. The value of pastureland also increased in all regions. The value of pastureland increased 70 to 76 percent in the South region and 19 to 23 percent in the Central region. The value of improved pasture increased about 15 percent in the northern regions. The value of unimproved pasture increased 9 percent in the Northeast and 12 percent in the Northwest.

Farm Woods. The value of farm woods increased 18 percent in the Northwest region and 16 percent in the Northeast region.

\section{Regional Comparisons of Land Values}

The most prominent change among regions this year was in the South region where land value increased 58 and 76 percent for cropland and pastureland, respectively. The largest increases were in the Indian River area, Okeechobee County, and the Gulf Coast counties. The other regions also experienced substantial increases: 19 to 25 percent in the Central region, 10 to 19 percent in the Northwest region, and 9 to 15 percent in the Northeast region.

The average value of citrus land was higher in the South region than in the Central region. The value of cropland and pastureland increased from $\$ 1,100$ to $\$ 1,400$ per acre in the South region during the past year. The value of improved pasture was higher in the Central region than in other regions. The lowest agricultural land values were reported in the Northwest region, ranging from $\$ 1,450$ per acre for unimproved pasture to $\$ 2,193$ per acre for irrigated cropland.

The average value of orange groves was $\$ 6,540$ per acre in the South region (about $\$ 130$ per acre higher than in the Central region). The estimated value of grapefruit groves increased to $\$ 5,264$ per acre in the South region (\$746 per acre higher than in the Central region). The average value of land with 5to 7-year-old citrus groves was $\$ 5,920$ per acre in the South region ( $\$ 580$ per acre higher than in the Central region).

The value of irrigated cropland was $\$ 3,901$ per acre in the South region, $\$ 3,709$ per acre in the Central region, and $\$ 3,428$ in the Northeast region. The value of nonirrigated cropland was $\$ 3,237$ per acre in the Central region, \$2,657 in the Northeast region, and $\$ 1,983$ in the Northwest region.

The value of improved pasture ranged from $\$ 3,608$ per acre in the Central region to $\$ 1,783$ per 
acre in the Northwest region. The value of unimproved pasture ranged from $\$ 2,605$ per acre in the South region to $\$ 1,451$ per acre in the Northwest region. The value of improved pastureland in the South region was 90.4 percent of the value in the Central region. However, the value of unimproved pasture was 15 percent higher in the South than in the Central region. The value of both types of pastureland in the Northwest region was about 65 percent of those in the Northeast region.

\section{Transition Land}

Transition land is defined as agricultural land that is being converted or likely to be converted to nonagricultural uses as sites for homes, subdivisions, and commercial uses. Counties were divided into metropolitan and non-metropolitan counties, and transition land values were estimated for each region. Metropolitan statistical areas (MSA) are classified by the U.S. Office of Management and Budget and are considered urban or urbanizing areas.

Non-metropolitan statistical areas are rural counties not included in the metropolitan statistical areas. Six counties have been re-classified and the new classifications are used in this analysis. Changes in the Northwest include moving Jefferson and Wakulla Counties into the Tallahassee MSA. Changes in the Northeast involved moving Gilchrist County into the Gainesville MSA and removing Flagler County from the MSA counties. In the South region, Indian River County was designated as the Vero Beach MSA. The transition land values for 2004 are not directly comparable with 2003 because of these classification changes. Transition land values were over 2.5 times higher in the Southeast region than in the other regions (Table 2).

The value of transition land within five miles of a major town in metropolitan counties increased 7 to 13 percent in the northern areas and 6 to 52 percent in the southern areas. The value of transition land within five miles of a major town in metropolitan counties ranged from $\$ 14,082$ to $\$ 24,983$ per acre, except in the Southeast region where transition land values were $\$ 62,500$ per acre. The value of transition land more than five miles from a major town in metropolitan counties ranged from $\$ 7,950$ to $\$ 14,352$ per acre, except in the Southeast region where transition land values were $\$ 36,250$ per acre. The value of transition land within five miles of a major town in the non-metropolitan counties ranged from $\$ 4,793$ to $\$ 6,778$ per acre, while transition land values more than five miles from a major town in the non-metropolitan counties ranged from $\$ 3,921$ to $\$ 5,446$ per acre.

\section{Cash Rents}

The estimated annual cash rent for nonirrigated cropland was $\$ 37.70$ per acre in the Northwest region and $\$ 34.68$ per acre in the Northeast region (Table 3). The estimated cash rent for improved pastureland was $\$ 27.87$ per acre in the Northwest region, \$23.84 per acre in the Northeast region, $\$ 21.90$ per acre in the Central region, and \$21.71 per acre in the South region. Cash rent for unimproved pastureland ranged from $\$ 18.52$ per acre in the Northwest region to $\$ 13.31$ per acre in the South region. The cash rent data indicate that cash rents increased for cropland and pastureland in all regions where adequate data were available.

Cash rent as a percentage of the estimated value ranged from 1.9 percent for nonirrigated cropland to 1.3 percent for unimproved pasture in the Northwest region. In the other regions, cash rent was 1 percent or less of the value of the land. These rates are low compared to other areas of the country and reflect strong nonagricultural demand for land based on the market value of agricultural and rural land in most areas of Florida.

\section{Expected Trends}

Survey respondents were asked if they expected agricultural land values to be higher, lower, or remain unchanged during the next 12 months. Eighty-five percent of the respondents in the northern areas and 67 percent in the southern areas expected agricultural land values to increase during the next year (Table 4). Only 2 percent of the respondents in the survey expected lower land values during the next 12 months. Except for the Southeast region, respondents expected land values to increase from 7 to 16 percent during the next 12 months. Respondents estimate that agricultural land values will increase 12.8 percent in the Northwest region and 12.6 percent in the Northeast region during the next year. In the southern 
areas, respondents expected agricultural land values to increase 6.9 percent in the Central region and 15.6 percent in the South region. Respondents estimate that that the Southeast region will have the largest increase of all regions at 30 percent, primarily due to strong urban demand on a limited supply of available land in this region.

\section{Using Survey Results}

The land value estimates provided in this report are based on the opinions of many people involved in the real estate market. Care must be exercised when making year-to-year comparisons between surveys for several reasons. First, the participating respondents change from year to year. Second, land use categories in some regions have fewer responses than previous years so statistical reliability differs from year to year. Third, government rules and regulations affecting water, land use, and the environment may change, affecting agricultural land values. Finally, with these changes and changes in counties designated as MSA counties, the results may not be directly comparable with results from previous years.

Despite these limitations, this survey has provided agricultural land value estimates that have been fairly consistent since the mid-1980s. These estimates serve as a guide to the relative average value of land uses within areas and between areas. Also, it is important to emphasize that the value of a specific tract of land may vary substantially from these estimates because of the physical characteristics of the tract, the location of the tract, and the economic and institutional factors that may affect or restrict its use. Therefore, the value of a specific tract of land should not be determined by these survey results.

\section{References}

Reynolds, John E. "Agricultural Land Values Increase: 2003 Survey Results." Florida Food and Resource Economics No. 151. University of Florida, Gainesville, FL, July-August 2003. Available online at http://www.agbuscenter.ifas.ufl.edu. 
Table 1. Estimated land value per acre by geographic region and land use, 2003 and 2004.

\begin{tabular}{|c|c|c|c|}
\hline \multirow[t]{2}{*}{ Region/Land Use } & \multicolumn{2}{|c|}{ Date } & \multirow[t]{2}{*}{ Percent Change } \\
\hline & May 2003 & May 2004 & \\
\hline & \multicolumn{2}{|c|}{ Dollars Per Acre } & $\%$ \\
\hline \multicolumn{4}{|l|}{ SOUTH } \\
\hline Mature Oranges & 5,932 & 6,540 & 10.2 \\
\hline Mature Grapefruit & 3,929 & 5,264 & 34.0 \\
\hline $\begin{array}{l}\text { 5- to 7-Year-Old Citrus } \\
\text { Cropland }\end{array}$ & \multicolumn{2}{|c|}{ Cropland } & 8.8 \\
\hline Irrigated & 2,475 & 3,901 & 57.6 \\
\hline Nonirrigated & 2,014 & $* * *$ & $* \star *$ \\
\hline \multicolumn{4}{|l|}{ Pastureland } \\
\hline Improved & 1,921 & 3,262 & 69.8 \\
\hline Unimproved & 1,487 & 2,605 & 75.7 \\
\hline \multicolumn{4}{|l|}{ CENTRAL } \\
\hline Mature Oranges & 5,721 & 6,409 & 12.0 \\
\hline Mature Grapefruit & 3,914 & 4,518 & 15.4 \\
\hline 5- to 7-Year-Old Citrus & 4,889 & 5,340 & 9.2 \\
\hline \multicolumn{4}{|l|}{ Cropland } \\
\hline Irrigated & 2,998 & 3,709 & 23.7 \\
\hline Nonirrigated & 2,597 & 3,237 & 24.6 \\
\hline \multicolumn{4}{|l|}{ Pastureland } \\
\hline Improved & 2,934 & 3,608 & 23.0 \\
\hline Unimproved & 1,899 & 2,267 & 19.4 \\
\hline \multicolumn{4}{|l|}{ NORTHEAST } \\
\hline \multicolumn{4}{|l|}{ Cropland } \\
\hline Irrigated & 3,148 & 3,428 & 8.9 \\
\hline $\begin{array}{l}\text { Nonirrigated } \\
\text { Pastureland }\end{array}$ & 2,366 & 2,657 & 12.3 \\
\hline Improved & 2,384 & 2,729 & 14.5 \\
\hline Unimproved & 2,080 & 2,268 & 9.0 \\
\hline Farm Woods & 1,847 & 2,140 & 15.9 \\
\hline \multicolumn{4}{|l|}{ NORTHWEST } \\
\hline \multicolumn{4}{|l|}{ Cropland } \\
\hline Irrigated & 1,986 & 2,193 & 10.4 \\
\hline Nonirrigated & 1,665 & 1,983 & 19.1 \\
\hline \multicolumn{4}{|l|}{ Pastureland } \\
\hline Improved & 1,542 & 1,783 & 15.6 \\
\hline Unimproved & 1,294 & 1,451 & 12.1 \\
\hline Farm Woods & 1,244 & 1,464 & 17.7 \\
\hline $\begin{array}{l}{ }^{* * *} \text { Insufficient data. } \\
\text { Source: Florida Land Value S } \\
\text { of Florida, May } 2004 .\end{array}$ & nt o & sol & s, University \\
\hline
\end{tabular}


Table 2. Estimated value of transition land by geographic region, May 2004.

\begin{tabular}{|c|c|c|c|}
\hline \multirow[t]{2}{*}{ Region/Category } & \multicolumn{2}{|c|}{ Date } & \multirow[t]{2}{*}{ Percent Change } \\
\hline & May 2002 & May 2003 & \\
\hline & \multicolumn{2}{|c|}{ Dollars Per Acre } & $\%$ \\
\hline \multicolumn{4}{|l|}{ METROPOLITAN COUNTIES } \\
\hline \multicolumn{4}{|l|}{$<5$ Miles to Major Town } \\
\hline Northwest & 13,167 & 14,082 & 6.9 \\
\hline Northeast & 15,500 & 17,751 & 13.4 \\
\hline Central & 16,029 & 18,575 & 13.2 \\
\hline South & 16,392 & 24,983 & 52.4 \\
\hline Southeast & 58,813 & 62,500 & 6.3 \\
\hline \multicolumn{4}{|l|}{$>5$ Miles to Major Town } \\
\hline Northwest & 7,000 & 7,950 & 13.6 \\
\hline Northeast & 7,813 & 9,023 & 16.1 \\
\hline Central & 10,388 & 12,500 & 20.3 \\
\hline South & 8,364 & 14,352 & 71.6 \\
\hline Southeast & 31,786 & 36,250 & 14.0 \\
\hline \multicolumn{4}{|c|}{ NON-METROPOLITAN COUNTIES } \\
\hline \multicolumn{4}{|l|}{$<5$ Miles to Major Town } \\
\hline Northwest & 4,312 & 4,793 & 11.2 \\
\hline Northeast & 5,400 & 6,473 & 19.9 \\
\hline Central & *** & $* * *$ & $* \star *$ \\
\hline South & 6,500 & 6,778 & 4.3 \\
\hline \multicolumn{4}{|l|}{$>5$ Miles to Major Town } \\
\hline Northwest & 3,475 & 3,921 & 12.9 \\
\hline Northeast & 4,088 & 5,446 & 33.2 \\
\hline Central & $* \star *$ & $* * \star$ & *** \\
\hline South & 4,375 & 4,833 & 10.5 \\
\hline
\end{tabular}


Nonagricultural Demand Causes Agricultural Land Values to Increase

Table 3. Cash rent by geographic region, May 2004.

\begin{tabular}{|c|c|c|c|c|}
\hline Item & Northwest & Northeast & Central & South \\
\hline & \multicolumn{4}{|c|}{ Dollars Per Acre } \\
\hline Improved Pastureland & 27.87 & 23.84 & 21.90 & 21.71 \\
\hline Unimproved Pastureland & 18,52 & 15.15 & $* * *$ & 13.31 \\
\hline Nonirrigated Cropland & 37.70 & 34.68 & *** & $\star \star \star *$ \\
\hline int data & & & & \\
\hline
\end{tabular}

Table 4. Respondents' expectations of land value changes over next 12 months by geographic region, May 2004.

\begin{tabular}{|cccc|}
\hline \hline Item & Higher & No Change & Lower \\
\hline & & Percentage of Responses \\
Southern Areas & 76 & 22 & 2 \\
Northern Areas & 85 & 13 & 2 \\
\hline \hline
\end{tabular}

